\title{
Lake water volume calculation using time series LANDSAT satellite data: a geospatial analysis of Deepor Beel Lake, Guwahati
}

Ishita Afreen Ahmed, Shahfahad and Mirza Razi Imam Baig

Department of Geography, Faculty of Natural Sciences, Jamia Millia Islamia, New Delhi, India

Swapan Talukdar

Department of Geography, University of Gour Banga, Malda, India

Md Sarfaraz Asgher

Department of Geography, University of Jammu, Jammu, India

Tariq Mahmood Usmani

Department of Geography, Aligarh Muslim University, Aligarh, India

Shakeel Ahmed

National Geophysical Research Institute CSIR, Hyderabad, India, and Atiqur Rahman

Department of Geography, Faculty of Natural Sciences, Jamia Millia Islamia, New Delhi, India
Lake water volume calculation

Received 23 February 2021 Revised 23 March 2021 Accepted 30 March 2021

\begin{abstract}
Purpose - Deepor Beel is one of the Ramsar Site and a wetland of great biodiversity, situated in the southwestern part of Guwahati, Assam. With urban development at its forefront city of Guwahati, Deepor Beel is under constant threat. The study aims to calculate the lake water volume from the water surface area and the underwater terrain data using a triangulated irregular network (TIN) volume model.

Design/methodology/approach - The lake water surface boundaries for each year were combined with field-observed water level data to generate a description of the underwater terrain. Time series LANDSAT images of 2001, 2011 and 2019 were used to extract the modified normalized difference water index (MNDWI) in GIS domain.

Findings - The MNDWI was 0.462 in 2001 which reduced to 0.240 in 2019 . This shows that the lake water storage capacity shrank in the last 2 decades. This leads to a major problem, i.e. the storage capacity of the lake has been declining gradually from 20.95 million $\mathrm{m}^{3}$ in 2001 to 16.73 million $\mathrm{m}^{3}$ in 2011 and further declined to
\end{abstract}

(C) Ishita Afreen Ahmed, Shahfahad, Mirza Razi Imam Baig, Swapan Talukdar, Md Sarfaraz Asgher, Tariq Mahmood Usmani, Shakeel Ahmed and Atiqur Rahman. Published in Frontiers in Engineering and Built Environment. Published by Emerald Publishing Limited. This article is published under the Creative Commons Attribution (CC BY 4.0) licence. Anyone may reproduce, distribute, translate and create derivative works of this article (for both commercial and non-commercial purposes), subject to full attribution to the original publication and authors. The full terms of this licence may be seen at http:// creativecommons.org/licences/by/4.0/legalcode

The authors are indebted to the Wildlife Division of Guwahati, Assam for providing in situ water level data of the Deepor Beel, Survey of India for providing the Toposheet from which the city map was obtained and USGS Earth Explorer server (https://earthexplorer.usgs.gov/) for providing the satellite data. The first author is thankful to University Grant Commission (UGC) for providing Maulana Azad National Fellowship (MANF) during this research work.

Conflict of interest: The authors declare that they have no conflict of interest.

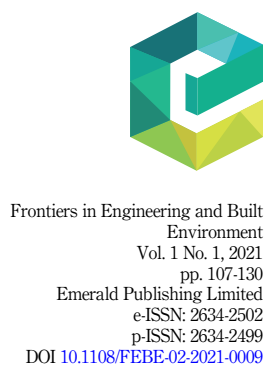


FEBE 1,1

15.35 million $\mathrm{m}^{3}$ in 2019. The fast decline in lake water volume is a serious concern in the age of rapid urbanization of big cities like Guwahati.

Originality/value - None of the studies have been done previously to analyze the decline in the volume of Deepor Beel lake. Therefore, this study will provide useful insights in the water resource management and the conservation of Deepor Beel lake.

Keywords Lake water volume, Deepor Beel lake, Modified normalized difference water index, Landsat satellite data, Surface water mapping, GIS technique

Paper type Research paper

\section{Introduction}

Lakes provide a wide range of ecosystem, socio-cultural as well as ecological services to humankind and nature (Sterner et al., 2020; Adrian et al., 2016). Optimal management of lakes entails a proper understanding of anthropogenic impacts both on the lake ecosystems and on the services, they provide for society (Lu et al., 2013). The specific structural and functional properties of lake morphology, hydrography, biogeochemical cycles and food-web structure are all directly related to their size and other lake characteristics (Tilahun and Kifle, 2020; Winslow et al., 2015). In this regard, the volume of water and its variations over time are fundamental properties of a lake as they affect the physical, chemical and biological processes of its ecosystems (Crétaux et al., 2016). Also, the water area at a given site or suite of sites determines the vegetation structure as well as the wildlife habitat and therefore strongly influences the interactions of nutrients, pesticides and other contaminants between lake sediments and its water column (Lane and D'Amico, 2010). Water volumes in lakes and rivers also reflect the equilibrium between rainfall and evaporation and interactions between surface and groundwater systems (Taubenböck et al., 2011; Medina et al., 2010).

Lakes all around the world are experiencing threats to its sustainability, including encroachment and anthropogenic alterations to the region's hydrology (Talukdar et al., 2021; Mishra and Griffin, 2010). Anthropogenic activities such as intensive extraction of fisheries resources, reclamation of land from marshes of wetlands, pollution discharge and development of water conservancy and have had a significant impact on lake ecosystems (Wang and Ma, 2016). Moreover, lakes located in urban areas all around the world are undergoing drastic changes in relation to both volume and area (Mallick, 2017; Shahjahan and Ahmed, 2016). Municipal wastewater discharges, failing septic systems and sewage overflows may contribute to create sanitary and environmental problems in urban lakes (Yang et al., 2020). Increasing population contributes to small as well as large scale land use land cover (LULC) changes, especially from the perception of demand for built-up area, industrial and agricultural activities (Panwar, 2017; Rahman et al., 2012). With the increase in urban population and expansion of big cities presents the severe problem between urban expansion and lake protection (Seto et al., 2012). It is noticed in India that since the land is limited so lakes are eaten up by being filled up with solid waste and mud and then buildings come up on such lands (Rashid and Aneaus, 2020; Mundoli et al., 2014). Moreover, urbanization and deforestation and will continuously have negative impacts on the nature of a water body and its ecosystem (Ghosh, 2019; Adugna et al., 2018).

The spatial as well as temporal changes in the volume of water bodies can be calculated by several methods depending on the availability of morphometric and areal data. Water volume, water area and water level are three key parameters of lake dynamics (Kumar et al., 2020). A long term and continuous water volume data can directly reflect the regional water supply and deficit (Geng et al., 2021). Moreover, our attention typically focuses on large lakes, following the oversight of small lentic water bodies when analyzing global-scale systems (Messager et al., 2016). Several studies exhibited the importance of small lakes for processes ranging from evaporation to sediment trapping, greenhouse gas emissions, catchment interactions, lake mixing, diagenetic reactions or aquatic habitat conservation (Holgerson and Raymond, 2016; 
Downing et al., 2008). Large lakes might dominate processes driven by volume or surface area due to their prevalence at a global scale, but small lakes contribute more to the total aquaticterrestrial interface than large lakes (Winslow et al., 2015).

In the last 20 years, multi-spectral remote-sensing images have been widely used for surface water monitoring. Many mapping methods have been proposed according to the characteristics of the water bodies' responsiveness to different spectral ranges. The normalized difference water index (NDWI) is used to delineate open water bodies with reflective near-infrared radiation and visible green light (McFeeters, 1996) and the improved version of NDWI by using short-wave infrared radiation and is renamed as modified normalized difference water index (MNDWI) are used continuously in the field of remote sensing to detect water bodies in small as well as large scale level (Xu, 2006). Landsat TM, ETM+ and OLI/TIRS, Moderate Resolution Imaging Spectroradiometer (MODIS), SPOT (Système Pour l'Observation de la Terre), ASTER (Advanced Spaceborne Thermal Emission and Reflection Radiometer) satellite images have been widely used to map the urban surface water (Sivanpillai and Miller, 2010; Bastawesy et al., 2008).

The Deepor Beel lake is one such small water body located in the Guwahati Metropolitan Area, Assam. The mapping of this urban lake is significant because it is a typical water-land eco-fragile zone that has been strongly affected by anthropogenic activities in recent decades. In particular, the problem of dumping municipal wastes, which accelerated the shrinking of water bodies and significantly altered the land cover state in the Deepor Beel area, and this process has been accompanied by many discussions about its environmental impacts (Mozumder and Tripathi, 2014). The main objective of the present study is to calculate changing dynamic of the water volume of the Deepor Beel. This study also explored the spatial and temporal patterns in and around the Deepor Beel during 2001-2019.

\section{Study area}

The Deepor Beel is a permanent, freshwater lake in a former channel of the Brahmaputra River sited in the south of the river in Kamrup Metropolitan district, $10 \mathrm{~km}$ southwest of Guwahati City, Assam. It is located between $26^{\circ} 06^{\prime} \mathrm{N}$ and $26^{\circ} 09^{\prime} \mathrm{N}$ latitude and $91^{\circ} 36^{\prime} \mathrm{E}$ and $91^{\circ} 41^{\prime} \mathrm{E}$ longitude with an altitude varies between 50 and $57 \mathrm{~m}$ amsl covering an area of about $40 \mathrm{~km}^{2}$ (Figure 1). The Beel is a large natural wetland having great biological and environmental importance besides being the only major stormwater storage basin for the Guwahati city (Goswami et al., 1999). It is of international importance under the Ramsar Convention been chosen as a Ramsar Site (No. 1207) in November 2002 for providing a framework for national action and international cooperation for the conservation and judicious use of wetlands and their resources (Deb et al., 2019).

Over time, the Beel has been facing numerous problems because of the accumulation of municipal solid wastes that are increasingly finding their way into the core area of the lake. The dumping of the solid wastes in its proximity at Boragaon by the Guwahati Municipal Corporation (GMC) has pushed the lake's pollution to alarming levels. The lake is shrinking rapidly since the last 2 decades due to rapid urbanization and this has led to jeopardy in the biodiversity of the lake and presently the degradation of the water body has reached a critical state.

\section{Data base and methodology}

\subsection{Data base}

Landsat 7 TM/ETM+ (Thematic Mapper/Enhanced Thematic Mapper Plus) and Landsat 8 (OLI/TIRS) satellite data of 2001, 2011 and 2019 were downloaded from (https://earthexplorer. usgs.gov/), is used for driving the various indices, LU/LC pattern and transformation.
Lake water volume calculation 
FEBE

\begin{tabular}{l}
1,1 \\
$\mathbf{1 1 0}$ \\
\hline
\end{tabular}

Figure 1.

Locational aspect and distribution of sampling points of study area
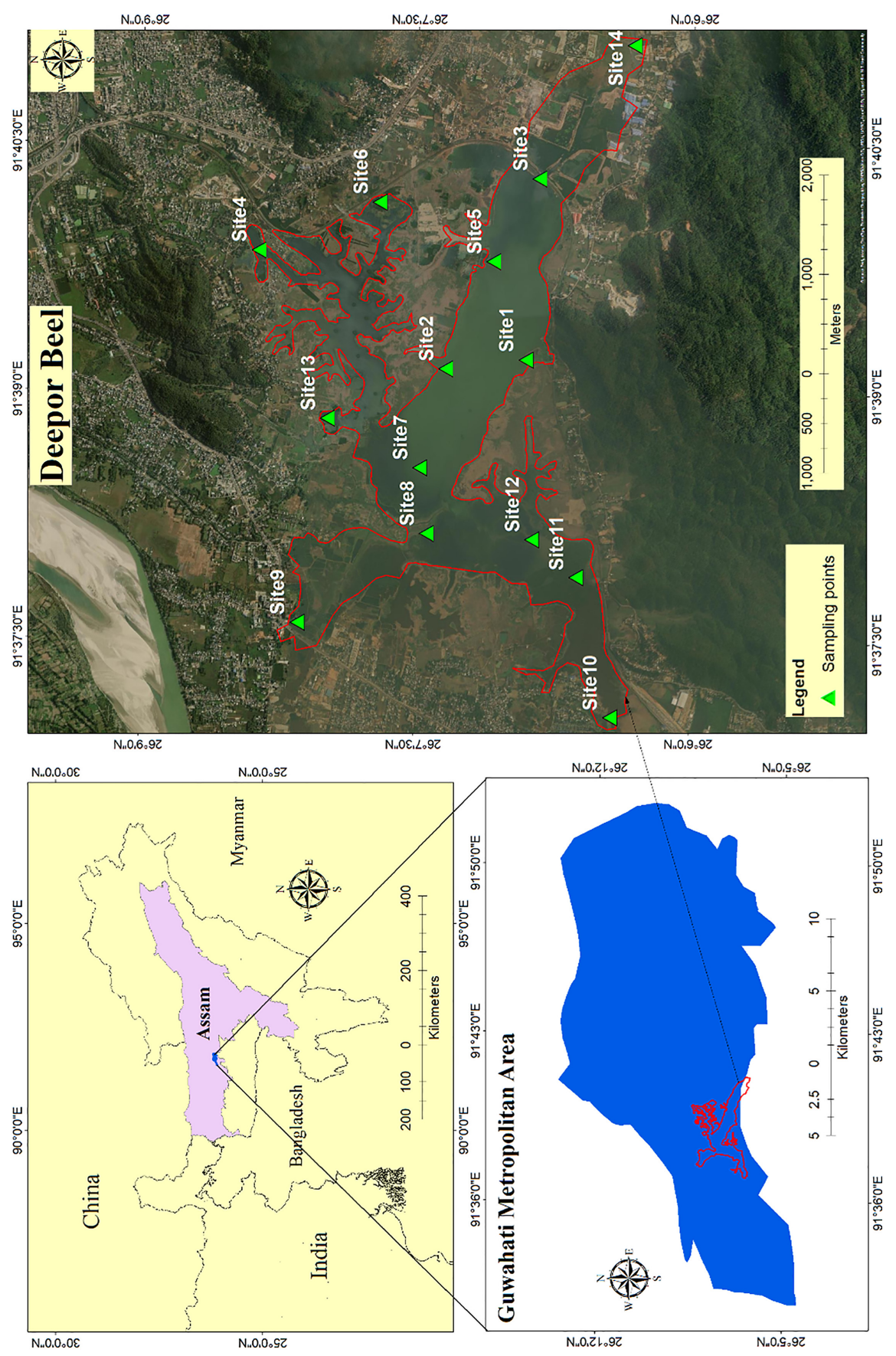
Toposheet obtained from Survey of India at a scale of 1:50,000 has been used to extract the map of the Kamrup Metropolitan district. Long-term water level data are collected from the Principal Chief Conservator of Forest and Head of Forest Force office, Guwahati, Assam. The distribution of the sampling points in the Deepor Beel has been shown in Figure 1 and the details of all the data sets used in the study have been shown in Table 1.

\subsection{Methods}

3.2.1 Land uselland cover. Five LULC groups were defined and categorized for 2001, 2011 and 2019 based on the spectral characteristics of satellite imagery and existing knowledge of land use in the study area. The classes viz. built up, vegetation, water bodies, rangeland and open land were identified in the study area based on National Remote Sensing Centre (NRSC), India LULC classification scheme (NRSA, 1995). Further, the accuracy of the classified maps was analyzed using Kappa coefficient. The results of accuracy assessment show an overall accuracy level of $85.55 \%, 87.75 \%$ and $89.42 \%$ for 2001,2011 and 2019 , respectively and the corresponding Kappa statistics was $0.835,0.887$ and 0.891 , respectively.

3.2.2 Surface water mapping. To correctly extract the water features, $\mathrm{Xu}$ (2006) proposed the MNDWI which is calculated using the Green and SWIR bands (equ. 1). The value of MNDWI ranges from the value of -1 to +1 . Finally, the higher reflectance of built-up and lower reflectance of water in the SWIR band result in negative values of built-up and positive values of water features in the MNDWI-derived image.

$$
\text { MNDWI }=\frac{\rho \text { Green }-\rho S W I R}{\rho \text { Green }+\rho S W I R}
$$

Where, $\rho$ Green is the green band and $\rho$ SWIR is the short-wave infrared band

Finally, the MNDWI-derived water surface images and LULC images (unsupervised classification) are compared and analyzed to obtain the trends and patterns of change in the surface area of Deepor Beel.

3.2.3 Underwater topographic modeling. Triangulated irregular network (TIN) model is considered as one of the superior methods for underwater topography simulation (Mi et al., 2007). TIN was chosen to simulate the underwater topography of the lake along with the morphology of the lake area with all the vector water level contours and DEM data. For the crisscrossing contours of the identical water level at different times, a blend of these was used. Lastly, the underwater terrain as well as the surrounding of the lake was modeled almost as a set of non-overlapping triangles. Individually, every triangle node has the coordinates $x, y$

\begin{tabular}{|c|c|c|c|c|c|c|}
\hline S. No. & \multicolumn{4}{|c|}{ Data source } & Year & Extractable information \\
\hline 1. & \multicolumn{4}{|c|}{ Google earth } & 2019 & City map, Deepor Beel map \\
\hline \multirow[t]{2}{*}{2.} & Satellite Data & Landsat 7 (TM & Path & row & & \\
\hline & $\begin{array}{l}\text { (USGS Earth } \\
\text { Explorer) }\end{array}$ & and $\mathrm{ETM}+)$ & 137 & 42 & $\begin{array}{l}2001 \text { and } \\
2011\end{array}$ & $\begin{array}{l}\text { Optical and Thermal Data } \\
\text { (Land use/cover, Vegetation, } \\
\text { Temperature etc.) }\end{array}$ \\
\hline 3. & & $\begin{array}{c}\text { Landsat } 8 \\
(\mathrm{OLI}+\mathrm{TIRS})\end{array}$ & 137 & 42 & 2019 & $\begin{array}{l}\text { Optical and Thermal Data } \\
\text { (Land use/cover, Vegetation, } \\
\text { Temperature etc.) }\end{array}$ \\
\hline 4. & \multicolumn{4}{|c|}{ Wildlife Division of Guwahati, Assam } & $\begin{array}{l}2001, \\
2011 \text { and } \\
2019\end{array}$ & $\begin{array}{l}\text { Hydrological data of Deepor } \\
\text { Beel (water level data) }\end{array}$ \\
\hline
\end{tabular}

Table 1.

Details of data sets used 
FEBE 1,1

\section{2}

and elevation value (depth of water, $z$ ), and each triangle surface has a certain slope angle. The sum of triangles in different areas depends on the actual topography. In flat areas, a fairly small number of triangles was generated and vice versa (Yin-Xi et al., 2016).

3.2.4 Lake water volume calculation. The volume of the lake water was calculated with the help of area and volume statistics module in ArcMap 10.3 3D Analyst Tool, in which the physical model of the given water body was formed with the intersection of the underwater terrain obtained from TIN and water surface data. The physical model created was then divided into several triangular prisms by projecting each triangle vertex to the water surface (see Figure 2). The volume of water was then calculated by adding the volumes of each triangular prism based on Mi et al. (2007) equation (2).

$$
V=\sum_{i=1}^{n} S_{i} \frac{\left(h_{i}+h_{i+1}+h_{i+2}\right)}{3}
$$

Where,

volt is the total volume $\left(m^{3}\right)$,

$S_{i}$ is the projection area $\left(\mathrm{m}^{2}\right)$ of the underwater terrain triangle surface on the water surface, $h_{i}, h_{i+1}$ and $h_{i+2}$ are the distance $(m)$ of the underwater triangle vertexes to the water surface, and $n$ is the number of triangular grids.

3.2.5 Mann-Kendall test. The Mann-Kendall statistical test has been frequently utilized to quantify the significance of trends in hydro-meteorological time series (Tabari, 2019; Silva et al., 2015; Duhan and Pandey 2013). The Mann-Kendall (Mann 1945; Kendall 1957) is calculated as:

Figure 2.

Methodology for storage calculation (Volume) of water body

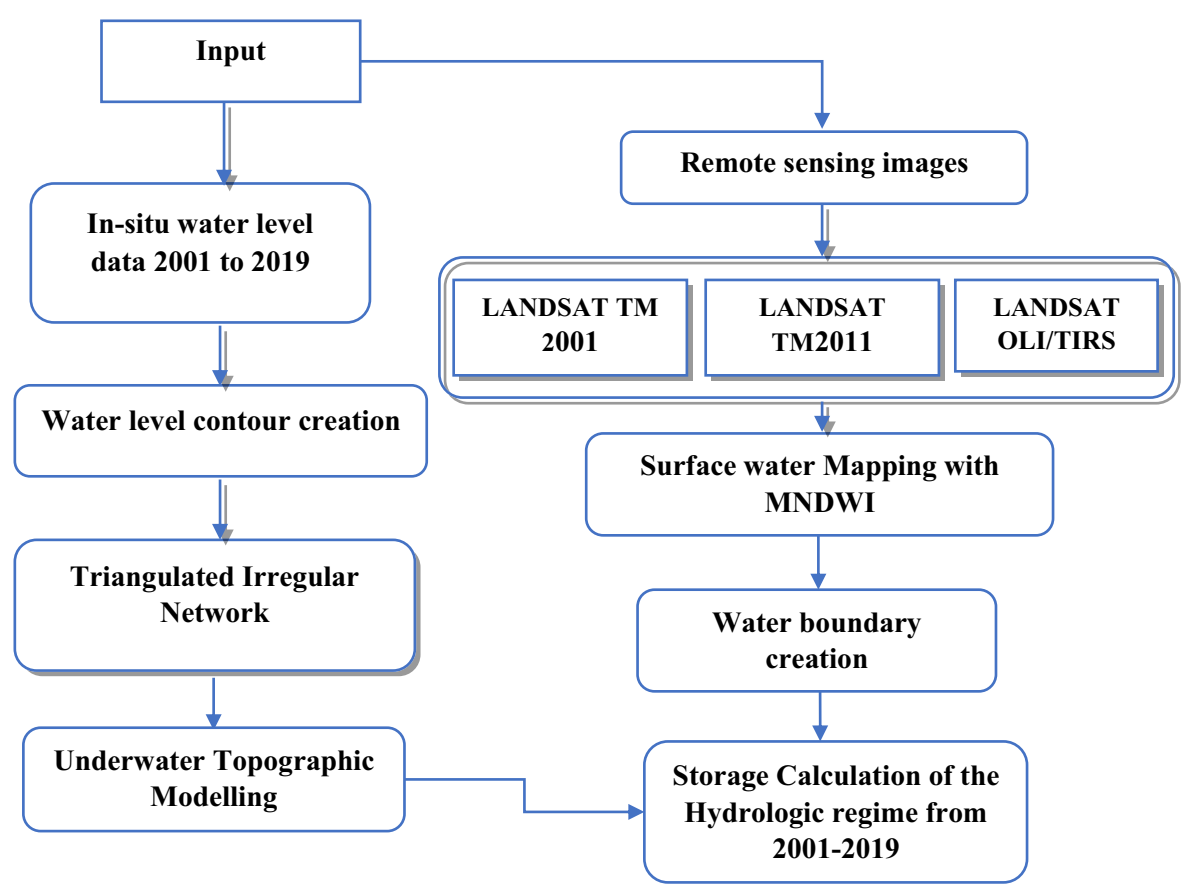




$$
s=\sum_{i=1}^{n-1} \sum_{j=i+1}^{n} \operatorname{sgn}\left(x_{j}-x_{i}\right)
$$

Lake water volume calculation

where $n$ is the number of data points, $x_{i}$ and $x_{j}$ are the data values in the time series $i$ and $j$ $(j>i)$, respectively, and $\operatorname{sgn}\left(x_{j}-x_{i}\right)$ is the sign function as:

$$
\operatorname{sgn}\left(x_{j}-x_{i}\right)=\left\{\begin{array}{ccc}
+1 & \text { if } & x_{j}-x_{i}>0 \\
0 & \text { if } & x_{j}-x_{i}=0 \\
-1 & \text { if } & x_{j}-x_{i}<0
\end{array}\right.
$$

The variance is computed as:

$$
\operatorname{Var}(S)=\frac{n(n-1)(2 n+5)-\sum_{i=1}^{P} t_{i}\left(t_{i}-1\right)\left(2 t_{i}+5\right)}{18}
$$

where $n$ is the number of data points, $P$ is the number of tied groups, the summary sign $(\Sigma)$ indicates the summation over all tied groups, and $t_{i}$ is the number of data values in the $P$ th group. If there are not any tied groups, this summary process can be ignored (Ay and Kisi, 2015).

A tied group is a set of sample data having the same value. In cases where the sample size $n>30$, the standard normal test statistic $z_{s}$ is computed using Eq. (6):

$$
Z_{S}=\left\{\begin{array}{cc}
\frac{S-1}{\sqrt{\operatorname{Var}(S)}} & \text { if } S>0 \\
0 & \text { if } S=0 \\
\frac{S+1}{\sqrt{\operatorname{Var}(S)}} & \text { if } S<0
\end{array}\right.
$$

Positive values of $Z_{S}$ indicate increasing trends whereas negative $Z_{S}$ values show decreasing trends. Testing trends is done at the exact significance level. When $\left|Z_{S}\right|>Z_{1-\alpha / 2}$, the null hypothesis is rejected and a significant trend exists in the time series. $Z_{1-\alpha / 2}$ is obtained from the standard normal distribution table. In this study, significance level $a=0.05$ is used. At the $5 \%$ significance level, the null hypothesis of no trend is rejected if $\left|Z_{S}\right|>1.96$ and vice versa.

3.2.6 Sen's slope estimator. Sen (1968) developed a nonparametric procedure for estimating the slope of trend in a sample of $n$ pairs of data. The Sen's method uses a linear model to estimate the slope of the trend, and the variance of the residuals should be constant in time calculated as:

$$
Q_{i}=\frac{X_{j}-X_{k}}{j-K} \text { for } i=1, \ldots, n
$$

where $X_{j}$ and $X_{k}$ are the data values at times $j$ and $k(j>\mathrm{k})$, respectively. If there is only one datum in each time period, then $N=n(n-1) / 2$, where $n$ is the number of time periods. If there are multiple observations in one or more time periods, then $M n(n-1) / 2$. The $n$ values of $Q_{i}$ are ranked from smallest to largest, and the median of slope or Sen's slope estimator is computed as: 
FEBE

1,1

\section{4}

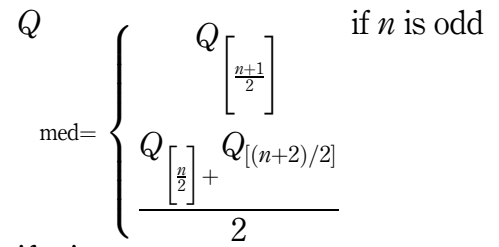

if $n$ is even

3.2.7 Statistical analysis. Also, a correlation matrix of the three main parameters of a water body namely, water level, surface water area and water volume were constructed for the urban lake. The correlation coefficient was in the present study to calculate and understand the relationship between the area and water volume as well as water level/depth and water volume of Deepor Beel. The linear correlation coefficient represented by $r$ measures the direction and strength of a linear relationship between two variables. The linear correlation coefficient is calculated with equation (8):

$$
r=\frac{n \sum x y-\left(\sum x\right)\left(\sum y\right)}{\sqrt{n\left(\sum_{x} 2\right)-\left(\sum_{x} 2\right)} \sqrt{n\left(\sum_{y} 2\right)-\left(\sum_{y} 2\right)} .}
$$

where $n$ is the number of pairs of data

The value of $r$ is such that $-1 \leq r \leq+1$.

\section{Results}

\subsection{Spatio-temporal changes of Deepor Beel Lake}

Rapid social and economic development has led to increased LULC changes in the urban areas all over the globe, which affect the surface energy balance and hydrological processes (Elmahdy et al., 2020). The result of the study shows a significant change in LULC around the Deepor Beel lake during 2001-2019. It is evident from Table 2 that the overall Deepor Beel Lake area shows a decrease over the past 2 decades. In 2001, the built-up areas were mostly concentrated in the east along with small patches in the northern and western parts of the lake (Figure 3a). But in 2011, most of the northern and central parts have been concretized (Figure 3b). In 2019, built-up areas could be seen all around the lake area replacing vegetative regions and open spaces (Figure 3c). Moreover, in 2001, the water extent of the Deepor Beel was from south-east to north-west spread over an area of 657.068 ha which decreased to 495.085 ha in the year 2019. The area of rangeland and vegetation have also significantly declined during the study period, especially in northern, eastern and western parts of the lake. Overall the maximum increase has been noticed in the built-up area $(248.47 \%)$ and the maximum decrease has been observed in vegetation $(-40.57 \%)$ followed by water bodies

\begin{tabular}{|c|c|c|c|c|c|c|c|}
\hline \multirow[b]{2}{*}{ S. No. } & \multirow{2}{*}{$\begin{array}{c}\text { LU/LC } \\
\text { Classes }\end{array}$} & \multicolumn{2}{|c|}{ Area (2001) } & \multicolumn{2}{|c|}{ Area (2011) } & \multicolumn{2}{|c|}{ Area (2019) } \\
\hline & & hectares & $\%$ & hectares & $\%$ & hectares & $\%$ \\
\hline 1. & Water bodies & 657.07 & 20.08 & 558.71 & 16.23 & 495.08 & 15.62 \\
\hline 2. & Built-up & 246.87 & 7.56 & 685.71 & 19.92 & 833.74 & 26.3 \\
\hline 3. & Vegetation & 1304.22 & 39.87 & 809 & 23.50 & 775.01 & 24.45 \\
\hline 4. & Rangeland & 704.49 & 21.54 & 683.05 & 19.84 & 660.85 & 20.84 \\
\hline 5. & Open land & 358.45 & 10.95 & 706.70 & 20.51 & 405.52 & 12.79 \\
\hline Total & & 3171.1 & 100.00 & 3171.17 & 100.00 & 3170.2 & 100.00 \\
\hline
\end{tabular}

Table 2.

Land use/land cover change of Deepor Beel (2001-2019) 


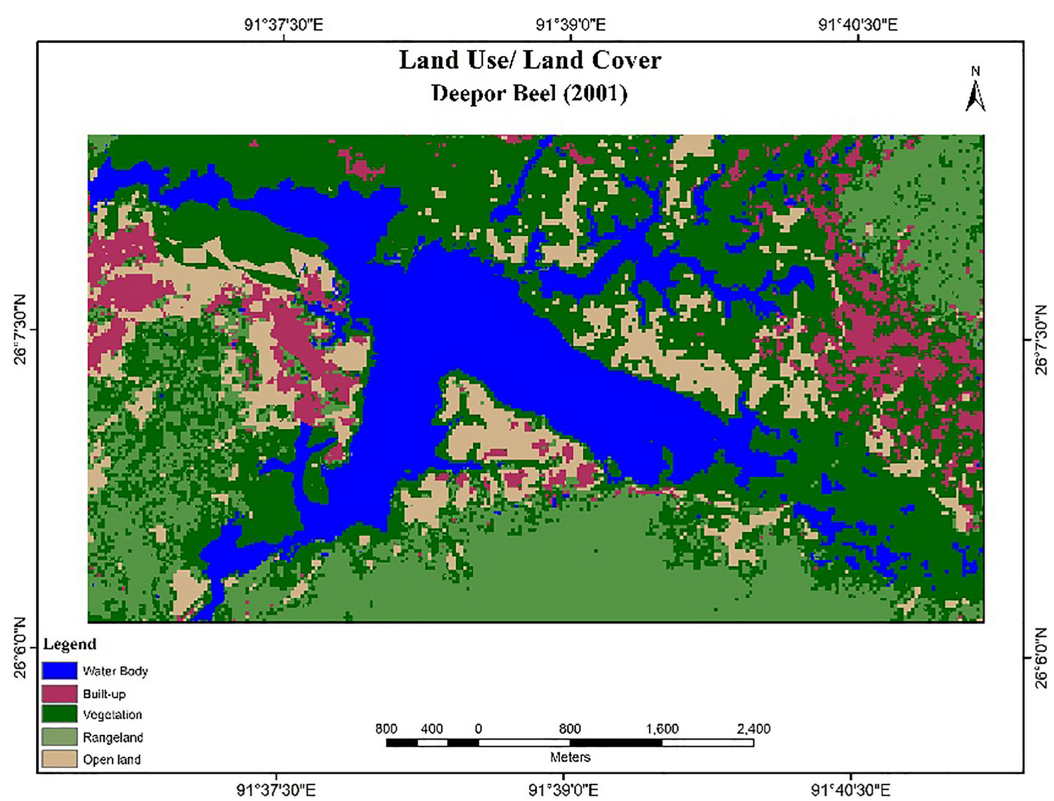

Lake water volume calculation

(a)

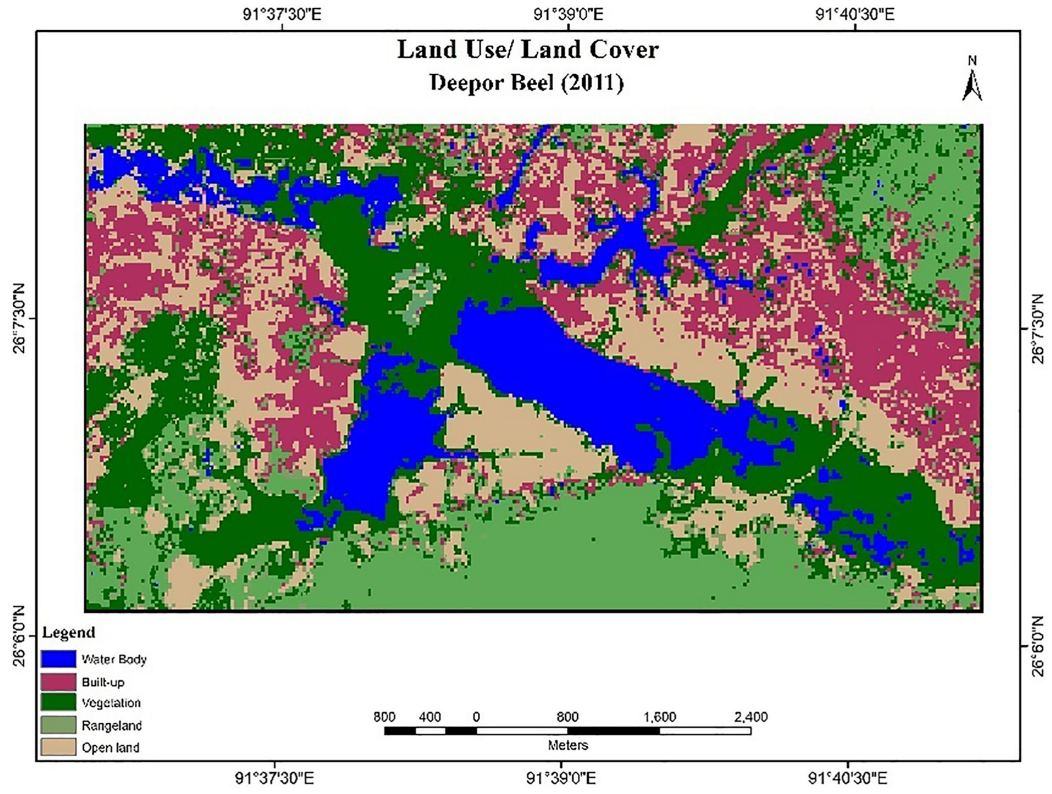

Figure 3.

Land use/land cover (a) 2001; (b) 2011 and (c) 2019 
FEBE

1,1

\section{6}

Figure 3.

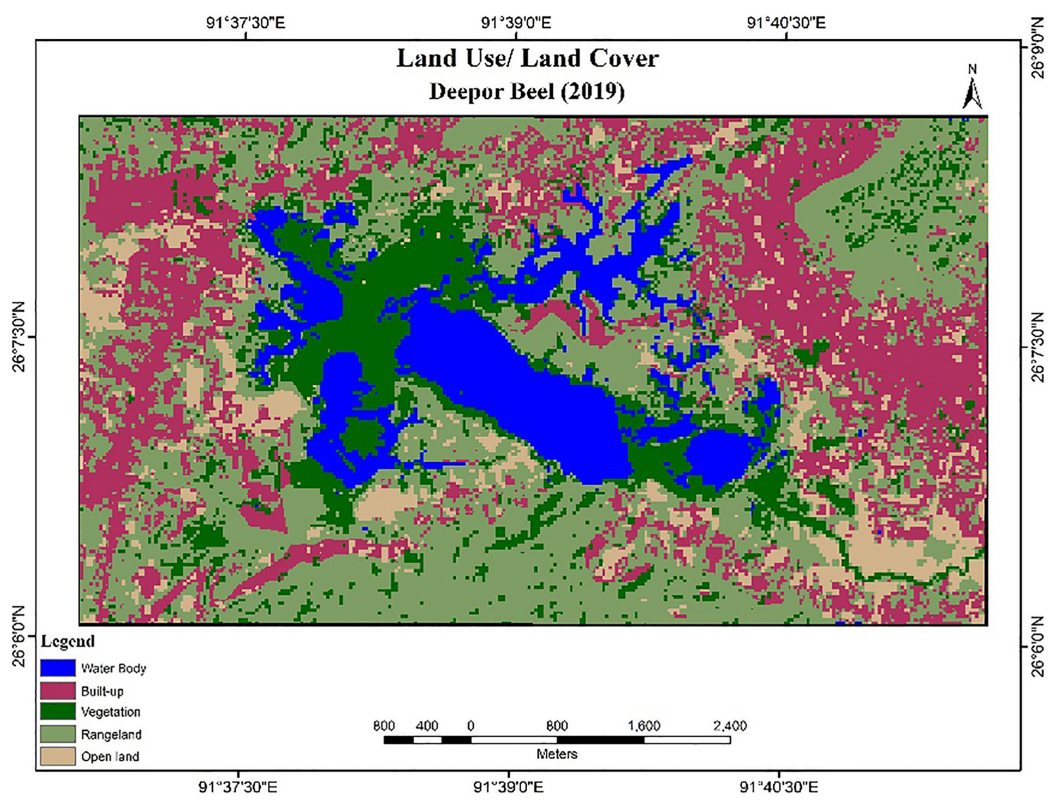

(c)

$(-24.65 \%)$. Various researches has showed change of water bodies as a result of urbanization and LULC change. These changes are mainly attributed to the human activities, especially land reclamation and aquaculture activities along the lakeshore (Liu et al., 2020; Wada et al., 2016; Song et al., 2013).

\subsection{Spatio-temporal variation of surface water in Deepor Beel}

The MNDWI in the Deepor Beel area is maximum in 2001 (Figure 4a-c), whereas 2011 and 2019 are highly concretized as validated with the LULC results (Table 2). Therefore, 2011 and 2019 have the least MNDWI values. In 2001, water bodies and vegetation are visible along with rangelands. Further in 2019, the dense amalgamation of apartments and buildings, where the tree cover along the roads, highways and open land around the Deepor Beel has become more dominating than the water body itself.

The lake water area was extracted using spectral water indexing. The analysis clearly shows that the shoreline of the Deepor Beel shrunk in the past eighteen years. Table 3 shows that the variations in the water surface area of Deepor Beel extracted from the LULC and MNDWI are quite similar. According to the MNDWI, between 2001 and 2019 there were drastic changes in the lake water area. The results reveal that the surface area of Deepor Beel lake in 2001 was approximately 659.05 ha (Table 3). By 2011, the surface area had decreased by approximately 101.12 ha. From 2001 to 2019, the lake lost about one-fourth of its surface area. However, from 2011 to 2019, the lake lost about one-tenth of its surface area (Table 3). According to the result given in Figure 4, the highest rate of water area change was observed in the south eastern and western part of the lake. Large-scale encroachment in the government as well as private-owned low-lying area of the Deepor Beel Ramsar site for various purposes such as settlements, institutions and business shops are causing tremendous threats to the water surface area of the lake. Figure $4(\mathrm{a}-\mathrm{c})$ clearly shows the change in the surface water boundary of Deepor Beel from 2001 to 2019. 


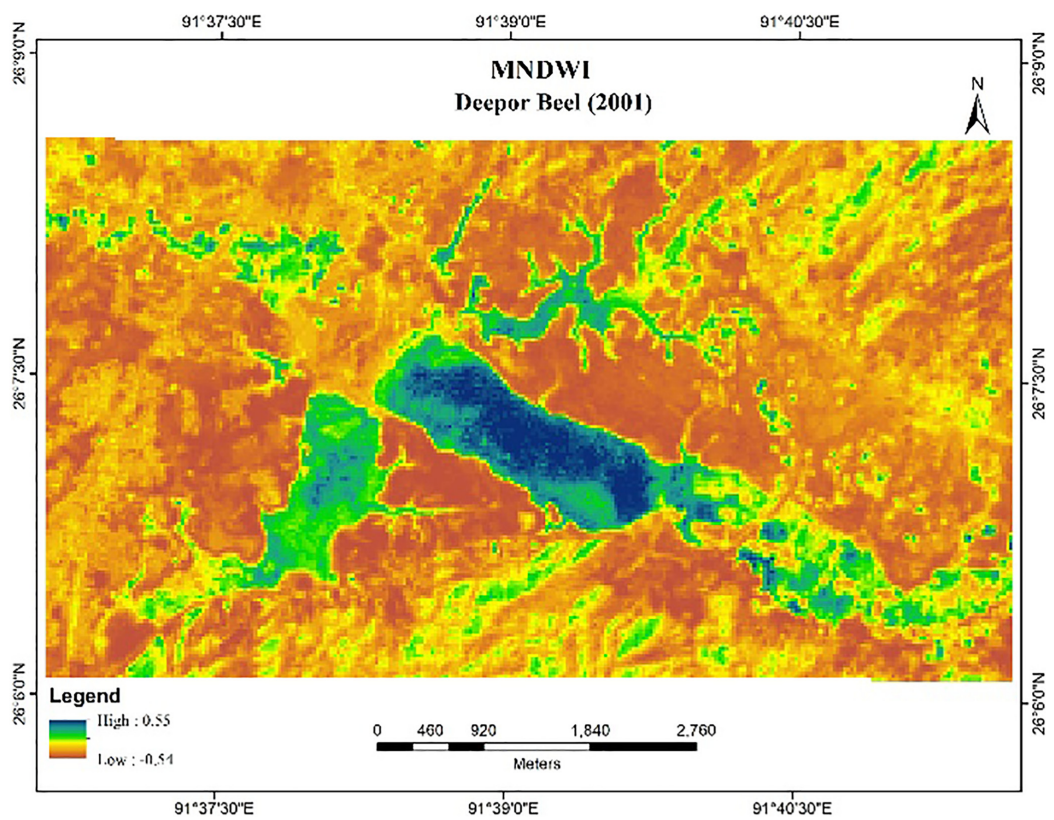

Lake water volume calculation

(a)

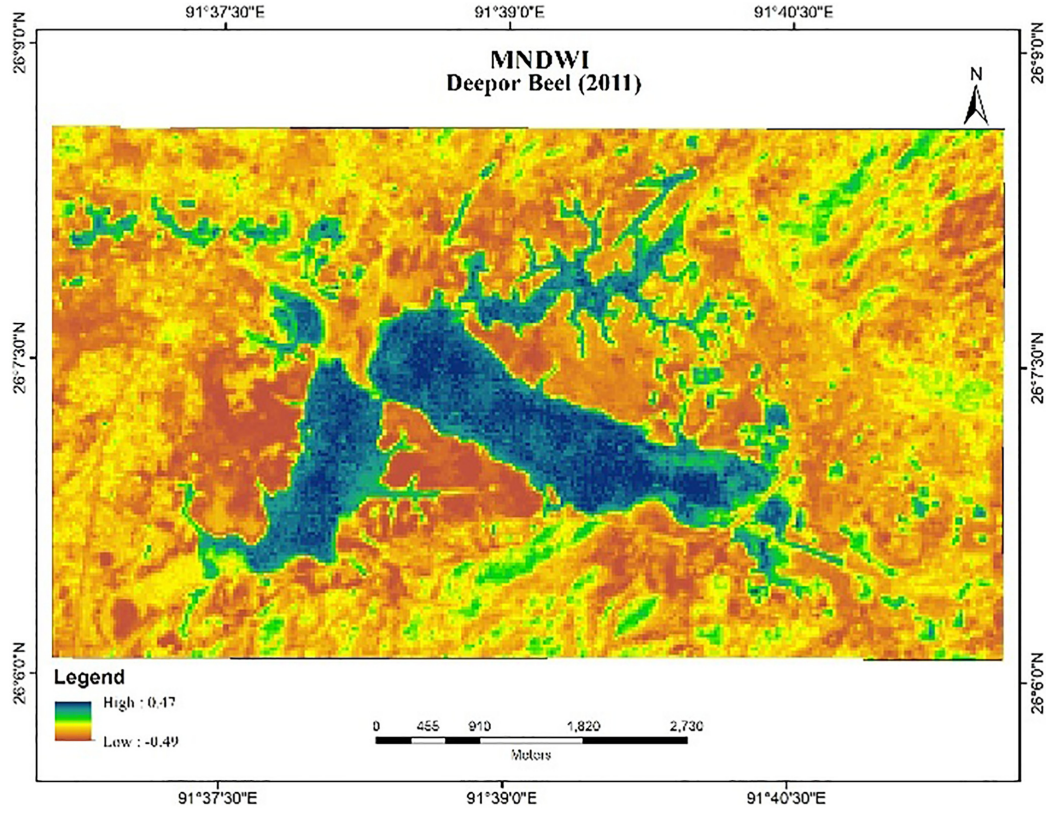

Figure 4.

MNDWI of Deepor Beel (a) 2001; (b) 2011 and

(b)

(c) 2019 


\section{FEBE 1,1}

\section{8}

Figure 4 .

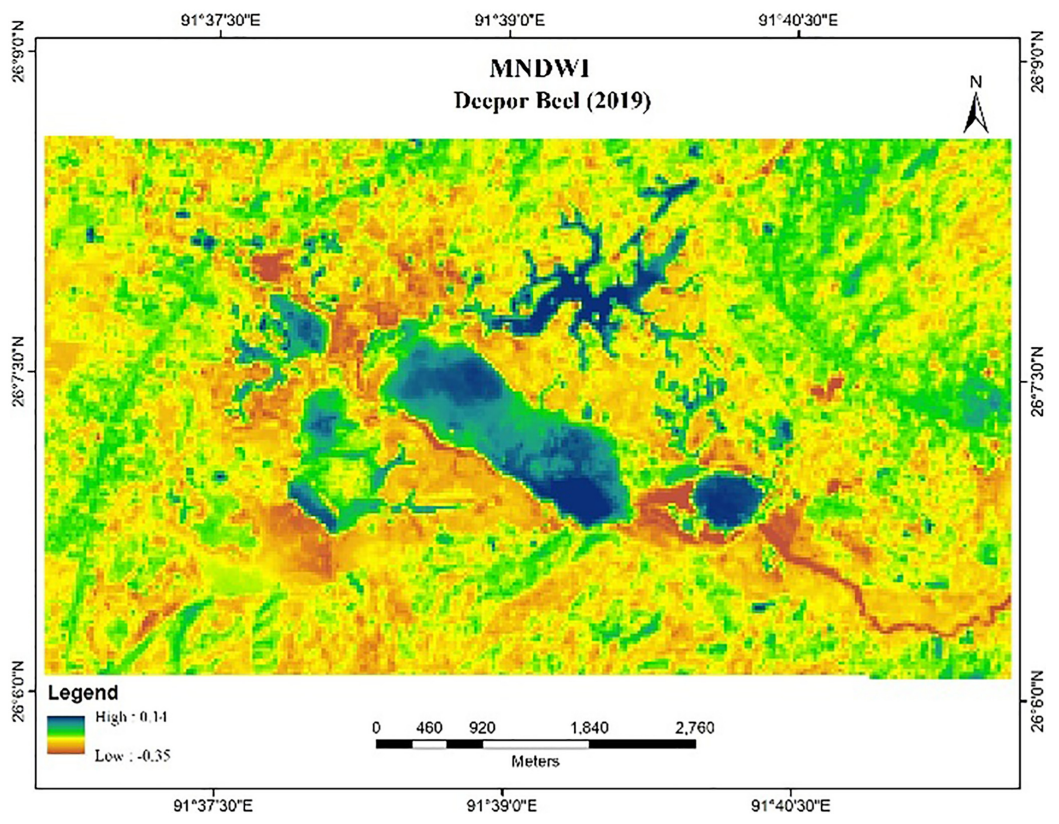

(c)
Table 3.

Variation in Deepor Beel surface water area using MNDWI and Unsupervised classification

\begin{tabular}{ll} 
S. & \\
No. & Years \\
\hline 1. & 2001 \\
2. & 2011 \\
3. & 2019
\end{tabular}

Surface water area using MNDWI (hectares)

659.05
557.93
500.34

Surface water area using unsupervised classification (hectares)

657.07

558.71

495.08

\subsection{Underwater terrain and morphology of Deepor Beel}

It is evident from Figure 5 that the basin bottom of the lake is relatively undulating and its flanks are steep, with slopes ranging from 0 to 2 degrees. The results indicate that the water level of Deepor Beel lake decreased over the past eighteen years. The interpolation map of the lake during the study period shows that the maximum water depth was $1.9 \mathrm{~m}$ whereas the lowest depth was $0.5 \mathrm{~m}$ (Figure 6). The water level shows a slight decrease in a total of $0.8 \mathrm{~m}$ from 2001 to 2019 (Table 4). The water depth profile clearly shows that the depth slowly increases from the centre of the lake (1.32-2.38 $\mathrm{m}$ ) toward the shoreline in the south (Figure 6). Furthermore, the depth of the lake suddenly drops in the frontal terminus, then reach a depth of $1.32-1.67 \mathrm{~m}$. The lake boundary of different years from vector data was also created to show the spatio-temporal changes (Figure $7 \mathrm{a}-\mathrm{c}$ ).

The northern and the eastern flanks of the lake are quite shallow as compared to the rest of the lake. This is mainly due to the active National Highway 37 which passes beside the eastern and northern side of the Beel, leading to the establishment of built-up patches and shops (vendors). Moreover, changes in the underwater terrain of the Deepor Beel are mainly caused by human activities, mainly urbanization leading to illegal sewage dumping. The western part is deeper in comparison to the rest of the lake. The western margins of the lake 


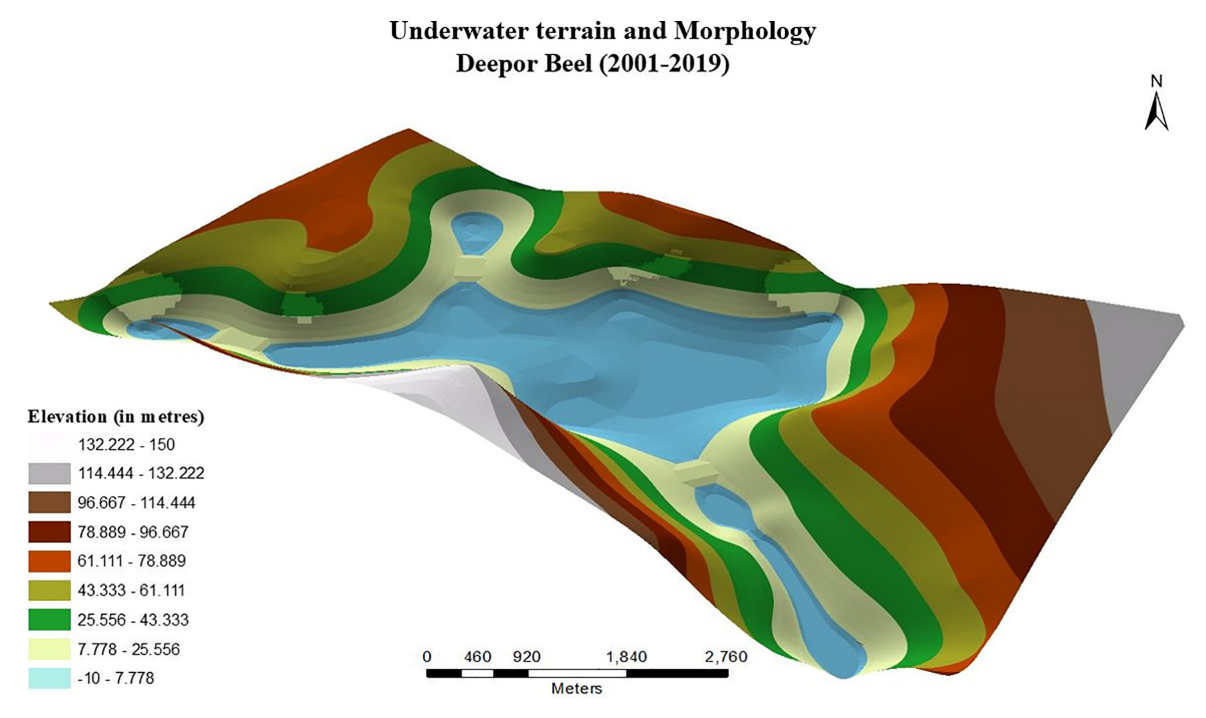

Lake water volume calculation

Figure 5.

Underwater terrain and morphological modeling of Deepor Beel and its surroundings 2001-2019

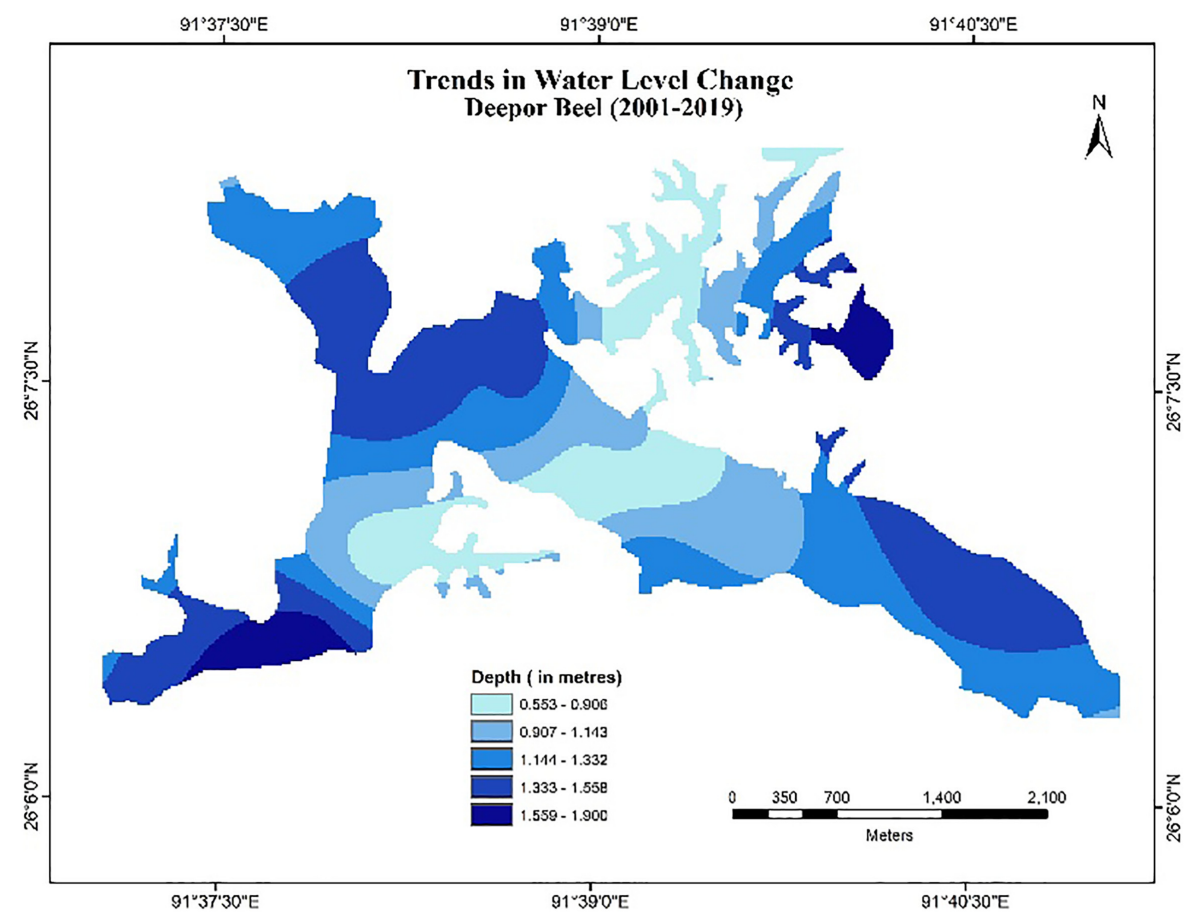

Figure 6.

Trend and pattern of water level of Deepor Beel lake from 2001 to 2019

are still a bit scarce on built up as compared to the other three sides. The southern part of the lake is the shallowest mainly because of the railway line constructed by the Northeast Frontier Railway around the Deepor Beel area (Figure 7). Since the 1960s, people living along 
FEBE 1,1

\section{0}

urban lakes have been using land near the lakeshore for farming and aquaculture (Dash et al., 2019). As a result, the area and water level of the lake has decreased sharply, and some natural shorelines have also disappeared.

\subsection{Volume of the Deepor Beel Lake}

During the study period, the proposed method calculated the volumes from 2001 to 2019 ranging from 20.95 to 15.35 million $\mathrm{m}^{3}$ from the underwater topographic modeling and water level, with a mean of 10.568 million $\mathrm{m}^{3}$. In 2001, the calculated water volumes were quite higher than in 2011 and 2019. The volume of the Deepor Beel has been declining very rapidly. The largest decrease in the volume of Deepor Beel occurred in the year 2019 (Table 5), possibly caused by wetland vegetation cover and haphazard establishment of settlements in the surrounding area. The storage capacity of the lake indicates a gradual decline during the study period, and the trend is statistically significant at the $5 \%$ significance based on the Mann-Kendall test (Table 6). The trend slope based on Sen's method exhibited that the decadal volume of the lake showed a significant decrease at the rate -2.8 million $\mathrm{m}^{3} /$ decade over the last 18 years.

Along with volume, it's related aspectsi.e area $(Z=-1.880)$ and depth $(Z=-5.947)$ also depicts a clear negative trend. The water level has decreased at a rate of $0.05 \mathrm{~m} /$ year (Table 6). Dumping of untreated waste has led to blockage of the natural drainage pattern of the lake causing an imbalance in the water level leading to a decline in the storage capacity of the lake. The water volume of a lake is a function of water level and surface water area, and a critical variable in the water mass budget of a lake catchment (Geng et al., 2021). Figure 8 shows a high correlation between the water volume and water surface area of Deepor Beel with a graphical representation from 2001 to 2019.

The adjacent forest areas around the lake are being cleared to supply timber for the sawmills, leading to heavy erosion, which in turn is causing rapid siltation in the Beel, further declining the storage capacity (Deb et al., 2019). Furthermore, brick factories and widespread soil cutting within the Beel ecosystem properly threatens the volume of the Beel (Islam and Gnauck, 2008). Urban lakes all over the globe are facing similar problems of declining volume, water area and level (Cai et al., 2020; Wufu et al., 2020). Such deterioration of quality of urban lakes are majorly caused due to anthropogenic activities (Wufu et al., 2020; Talukdar and Pal, 2019; Lu et al., 2013).

\subsection{Validation and auxiliary data}

The validation of the in situ water level data and the calculated storage capacity of Deepor Beel is done with a correlation matrix which is shown in Table 7.

The main aim to study the volume of water bodies is to develop a mathematical equations relating area and volume to depth and water level using morphometric data. While validating the calculated storage capacity there are obvious discrepancies within the measured values. By comparing the values of correlation coefficient $(r)$ it was clear that the water level has a direct positive relationship with the volume of the lake (Table 7). Additionally, the surface water area also shows a strong positive significance with water volume $(r=0.951)$. After

\section{Table 4.}

Average, maximum and minimum water surface level of Deepor Beel (2001, 2011 and 2019)

\begin{tabular}{lcccc}
\hline S. No. & Years & Mean $(\mathrm{m})$ & Maximum $(\mathrm{m})$ & Minimum $(\mathrm{m})$ \\
\hline 1. & 2001 & 1.77 & 1.82 & 1.25 \\
2. & 2011 & 1.27 & 1.89 & 0.75 \\
3. & 2019 & 0.97 & 1.59 & 0.45 \\
\hline
\end{tabular}




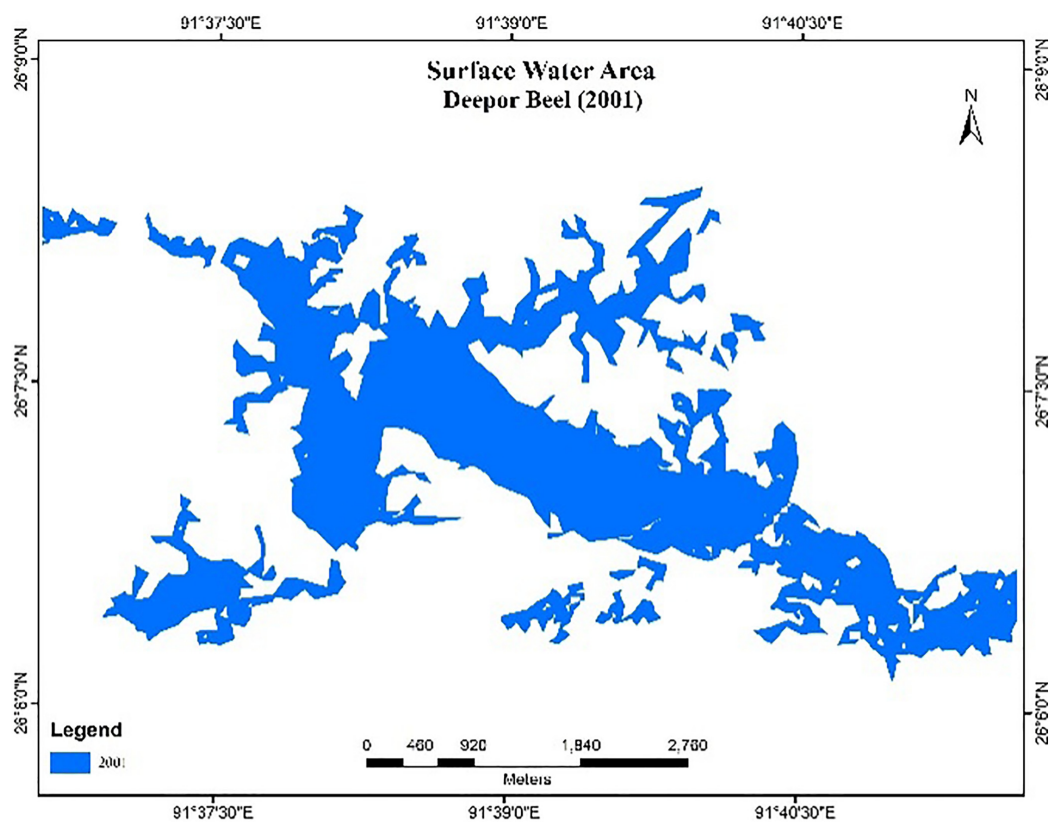

(a)

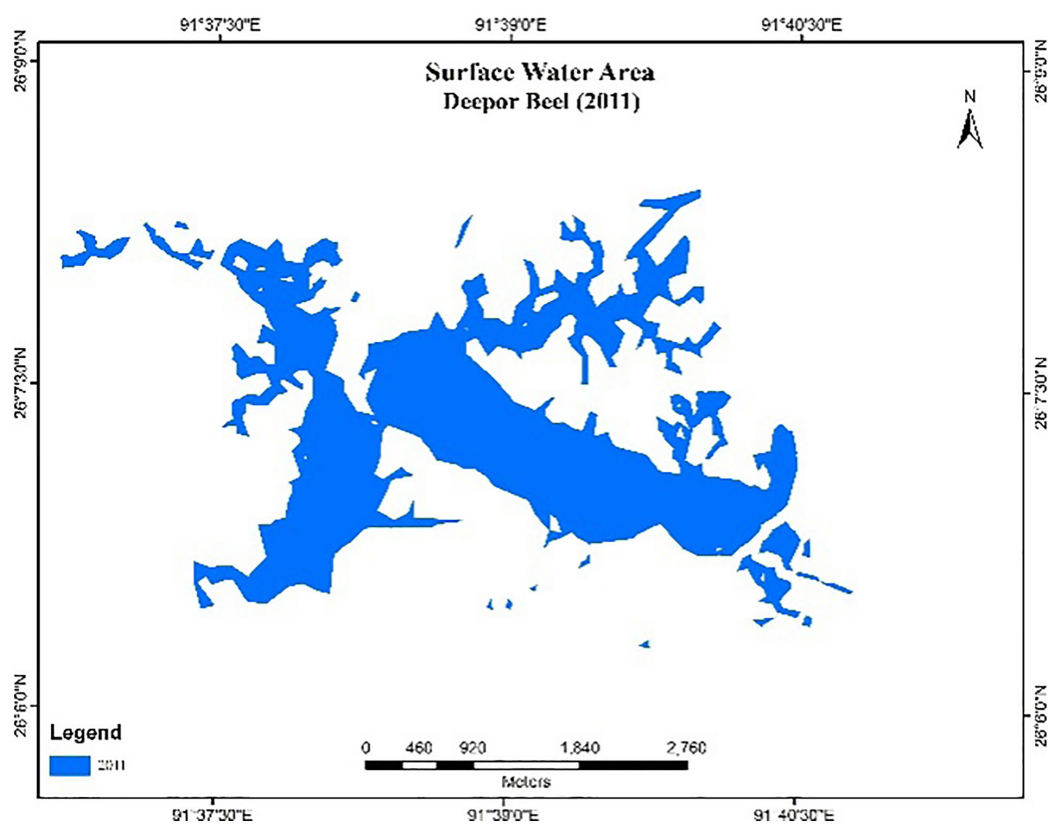

(b)
Lake water volume calculation

Figure 7.

Deepor Beel Lake surface area change map (a) 2001; (b) 2011 and (c) 2019 
FEBE

1,1

122

Figure 7.

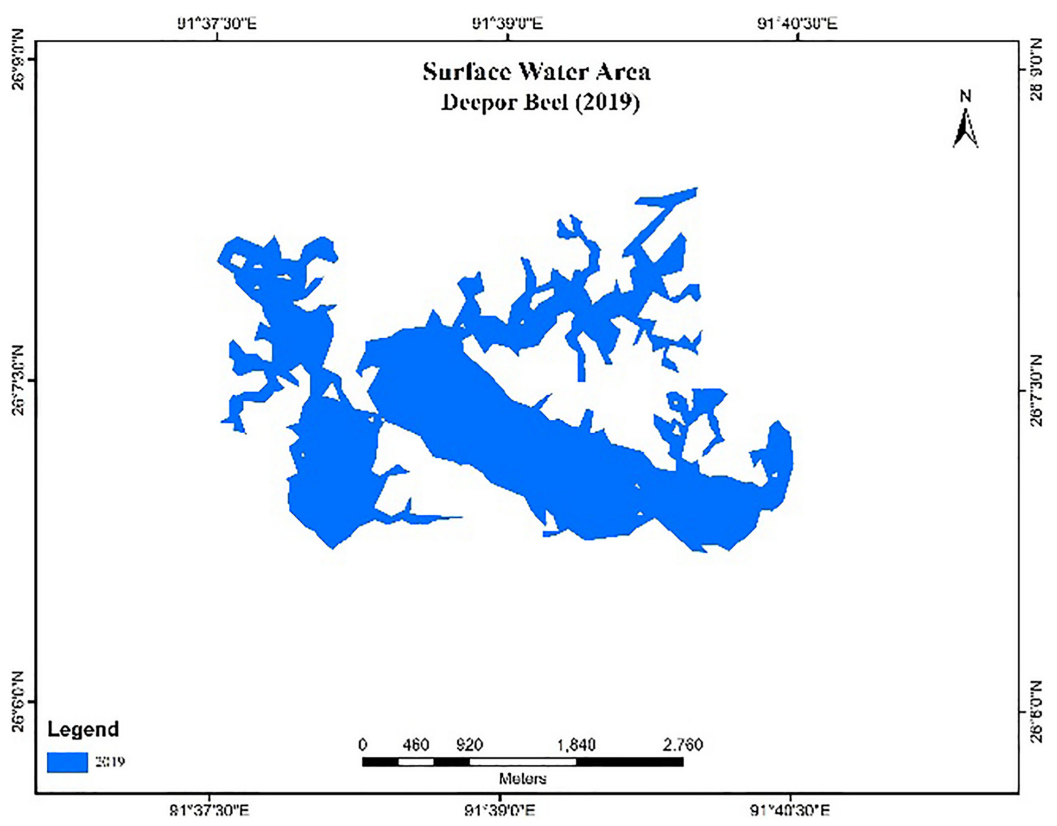

(c)

Table 5.

Calculated volume of water and area of the Deepor Beel

\begin{tabular}{lccc}
\hline S. No. & Years & Volume $\left(\right.$ million $\mathrm{m}^{3)}$ & Area $\left(\mathrm{km}^{2}\right)$ \\
\hline 1. & 2001 & 20.95 & 29.88 \\
2. & 2011 & 16.73 & 25.24 \\
3. & 2019 & 15.35 & 23.65 \\
\hline
\end{tabular}

Table 6.

Mann-Kendall trend test and Sen's slope test of water volume, water surface area and water level of Deepor Beel

\begin{tabular}{lcccc}
\hline & $\begin{array}{c}\text { Mann-Kendall } Z \\
\text { value }\end{array}$ & $\begin{array}{c}\text { Mann- Kendall } \\
\text { statistics }(S)\end{array}$ & $\begin{array}{c}\text { Kendall's Tau } \\
(\tau)\end{array}$ & $\begin{array}{c}\text { Sen's slope estimator } \\
\left(Q_{i}\right)\end{array}$ \\
\hline Water volume & -1.045 & 1.00 & 0.018 & -2.8 \\
Water surface & -1.880 & 1.02 & 0.052 & -3.51 \\
area & -5.947 & -171 & -1 & -0.005 \\
Water level & & & -1 & \\
\hline
\end{tabular}

developing the correlation coefficient matrix, scatter diagrams were constructed and shown in Figure $9 \mathrm{a}-\mathrm{d}$, respectively. The linear models thus obtained shows that the correlation coefficient between water volume, area and water level (average, maximum and minimum) demonstrates a statistically significant decline over time. In both cases, i.e. correlation coefficient and linear model, the objective is to establish a relation between water levelvolume as well as area-volume (Zhang et al., 2019; Arabsahebi et al., 2019). Besides, the in situ 


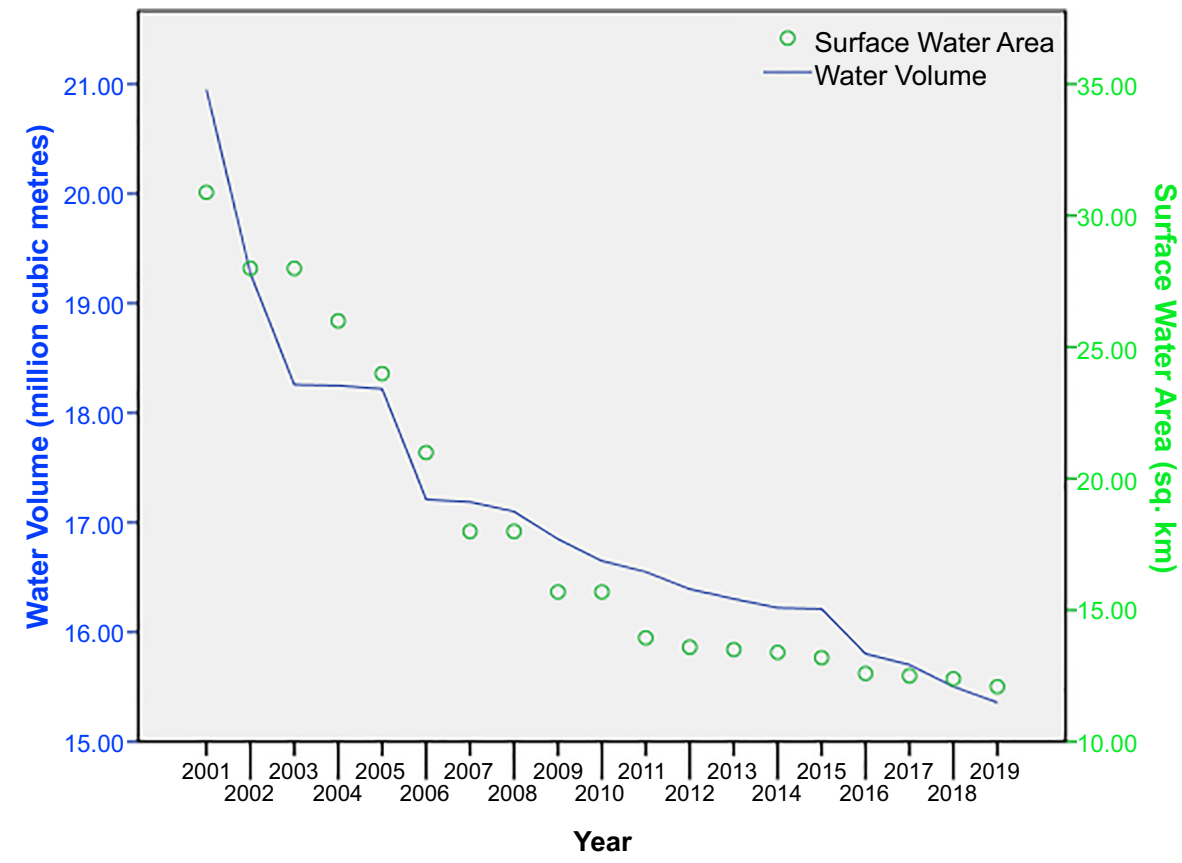

\begin{tabular}{llcccc}
\hline \multicolumn{2}{c}{ Correlation Coefficient $(r)$} & $\begin{array}{c}\text { Water surface } \\
\text { area }\end{array}$ & $\begin{array}{c}\text { Water level } \\
\text { (mean) }\end{array}$ & $\begin{array}{c}\text { Water level } \\
\text { (max.) }\end{array}$ & $\begin{array}{c}\text { Water level } \\
\text { (min.) }\end{array}$ \\
\hline $\begin{array}{l}\text { Water } \\
\text { volume }\end{array}$ & $\begin{array}{l}\text { Pearson } \\
\text { correlation }\end{array}$ & $0.951^{* *}$ & $0.809^{* *}$ & $0.810^{* *}$ & $0.810^{* * *}$ \\
& $\begin{array}{l}\text { Sig. (2-tailed) } \\
\text { (m) }\end{array}$ & 0.000 & 0.000 & 0.000 & 0.000
\end{tabular}

Note(s): ${ }^{* *}$ Correlation is significant at the 0.01 level (2-tailed) ${ }^{*}$ Correlation is significant at the 0.05 level (2-tailed)
Lake water volume calculation

123

Figure 8. Changes in the volume and area of Deepor Beel lake from 2001 to 2019

Correlation coefficient between water volume, water surface area and water level of Deepor Beel

water level data along with the calculated storage capacity and surface water area clearly shows decline in different years from vector data of the lake boundary.

\section{Discussion}

The LULC derived images of the Deepor Beel shows a variation in the land use patterns around the lake from 2001 to 2019. The LULC maps of three observation periods (Figure 3ac), clearly shows that the surface water area of the Deepor Beel lake (657.07 ha in 2001, 558.71 ha in $2011 ; 495.08$ ha in 2019) is continuously decreasing whereas area coverage by built-up (246.87 ha in 2001, 685.71 ha in 2011; 833.74 ha in 2019) around the Beel is continuously increasing from 2001 to 2019. The establishment of the Gopinath Bordoloi International Airport, the National Highway no. 37, and the railway line constructed by the Northeast Frontier Railway are the key aspects that play a major role in the land use pattern around the Deepor Beel area. The greenery in and around the lake area is no more to be seen (Mozumder et al., 2014). Due to the migration of population in search of livelihood into the city, 


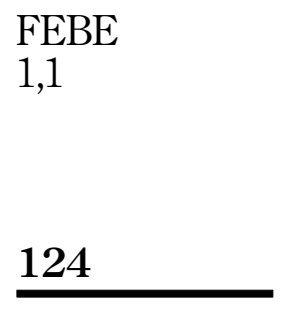

Figure 9.

Scatter plot for average, maximum and minimum water level with water volume and surface water area

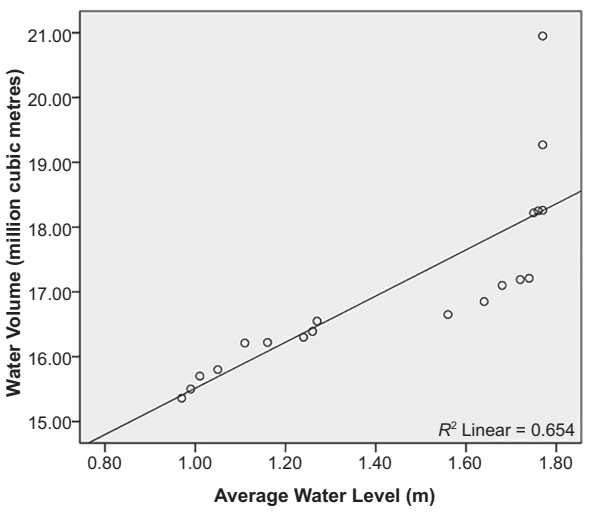

(a)

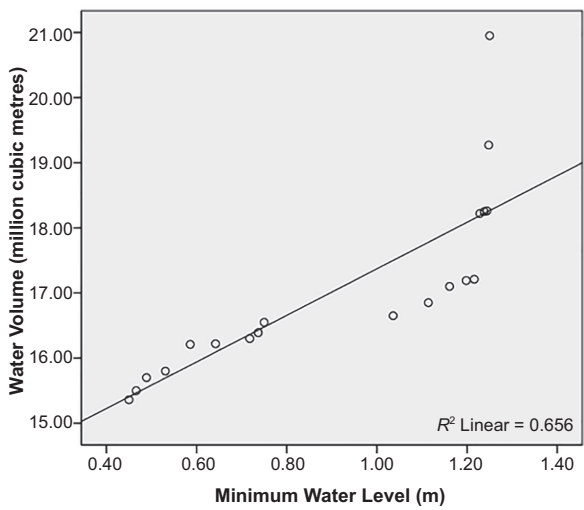

(c)

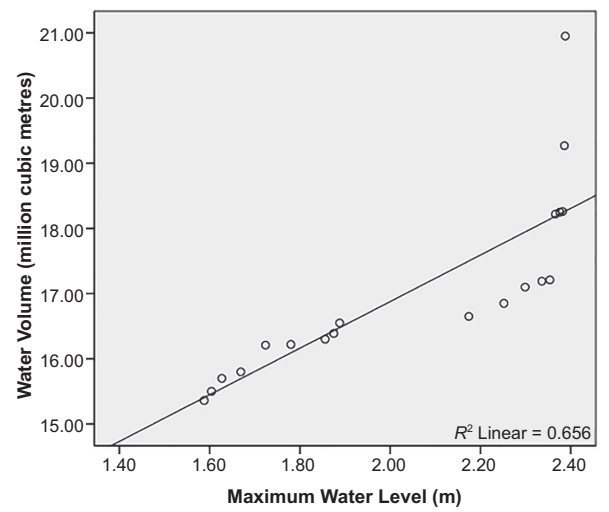

(b)

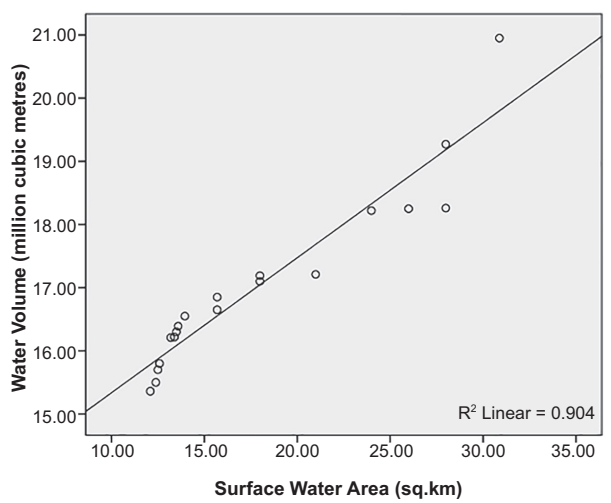

(d)

the suburb areas including the Deepor Beel wetland areas around the Guwahati city are rapidly filling up for residential, educational, industrial purposes which severely affected the wetland ecosystem. Such scenarios are quite common in the $21^{\text {st }}$ century urban water bodies all over the globe (Cai et al., 2020; Yan et al., 2019; Talukdar and Pal, 2019; Ganaie et al., 2017). The natural drainage pattern of the lake is mostly blocked causing an imbalance in the water level. Dumping of industrial and untreated domestic waste by the GMC at the municipal garbage dumping site at Paschim Boragaon near Deepor Beel cause enormous water and land pollution which in turn resulted into the destruction of numerous species of flora and fauna in the surrounding area (Dash et al., 2019). Besides, during the monsoon season, the surface runoff usually sweeps away the waste materials from the dumping site then mixing of this into the lake water deteriorating the water quality (Wu et al., 2017).

Furthermore, the modified normalized water index proved itself to be the most accurate method to detect, measure and monitor the urban surface water bodies because they can easily differentiate dry land and water bodies (Saha et al., 2020). With the assumption that LULC as constant with time may not give reliable outputs or results and may deviate from observed and simulated results in hydrological modeling. The surface area of the Deepor Beel was extracted from both the MNDWI and LULC results. Thus, accurate classification of features plays important roles in modeling of hydrological system. In this study, both the outputs showed identical values. Also, the result of MNDWI shows that in the last eighteen 
years, the urban aquatic ecosystem of Deepor Beel has been decreasing more than 150 ha. Guwahati city, especially, the outskirts are experiencing massive urban development such as housing and residence in which many forests areas and open spaces such as field and swamps are converted (Pawe and Saikia, 2017). As a result, the urban water body is getting smaller and smaller because water bodies or vegetation area are mostly converted to built-up areas (Cai et al., 2020; Modi et al., 2019; Wu et al., 2017). The MNDWI method is very effective as it can suppress information about land built effectively by highlighting water information and accurately extracting information from water bodies $(\mathrm{Xu}, 2006)$ in the study area. The results show that MNDWI can improve water bodies and suppress built-up capabilities very efficiently, thus extracting the area of the water bodies.

Furthermore, the underwater terrain and morphology modeling with the help of the fieldobserved water level data, DEM and triangulated irregular network (TIN) clearly shows changes in the basin morphology (Lu et al., 2013) of the Deepor Beel lake. The TIN based method has broad implications for water storage change monitoring in lakes with annual variations in water level (Yao et al., 2012). The volume of the Deepor Beel lake has been decreasing in the three proposed timed period from 20.95 million $\mathrm{m}^{3}$ in 2001 to 16.73 million $\mathrm{m}^{3}$ in 2011 to 15.35 million $\mathrm{m}^{3}$ in 2019. A rapid urban expansion has been identified around the Deepor Beel which endangers the green environment in and around the urban lake (Mozumder and Tripathi, 2014). This has led to human mismanagement to intensify pollution and loss of habitat for birds and fish in the lake area (Modi et al., 2019). Moreover, construction of broad-gauge railway line connecting Guwahati with Bongaigaon through the south bank of the Brahmaputra river with a bridge at Jogighopa cuts across the lake and wastewater from different parts of the city and the adjoining areas (Goswami, 2012) and Pamohi as well as Paschim Boragaon garbage dumping site adjoining the Deepor Beel are the major anthropogenic causes for the deterioration of the storage capacity of the lake.

Our analysis similar to several previous studies, also depicts that the surface area and water level are important factors in determining the storage capacity (Zhang et al., 2017; Arabsahebi et al., 2019). The surface area of the Deepor Beel lake has been declining along with decline in water level from 2001 to 2019. When all the water parameters are treated independently forthe calculation of contribution to the decrease or increase of storage capacity, validation with the help of the correlation matrix revealed that that water volume is affected by both water surface area $(r=0.951)$ and water level $(r=0.809)$. This condition is further proceeded with the linear model function. The coefficient correlation along with the linear model function validates that the Deepor Beel lake demonstrates a statistically significant declining trend of volume, area and water level over time.

The Preservation and Conservation Act, 2008 has been put in place to stop illegal construction activities in and around Assam's lone Ramsar site, Deepor Beel. In particular, the Guwahati Metropolitan Development Authority started clearing illegal newly occupied areas, and illegal occupation was curbed (Joshi and Solanki, 2019). However, many areas around the lake are still used for reclamation and aquaculture that have not been cleared (Dash et al., 2019; Goswami, 2012). In addition to the reduction in water area and storage capacity, disorderly farming and aquaculture can affect the water quality of lakes (Cai et al., 2020) like Deepor Beel (Bhattacharyya and Kapil, 2010). Moreover, in March 2015, it was reported that the Kamrup (Metropolitan) district administration has ordered the GMC to shift its garbage disposal project from Deepor Beel (Joshi and Solanki, 2019). Therefore, the work of construction, farming and aquaculture areas to lake area should continue to be strictly carried out around Deepor Beel, and the monitoring and management of the lake should also be maintained.

\section{Conclusion}

The present study clearly shows that the LULC changes around the Deepor Beel was significant during the period from 2001 to 2019. Also, from 2001 to 2019, the lake lost about

Lake water volume calculation 
FEBE 1,1

one-fourth of its surface area and from 2011 to 2019, the lake lost about one-tenth of its surface area. Moreover, the inland urban lake of Deepor Beel is shrinking with declining storage capacity mostly due to the inflow of wastewater from Guwahati city to this Beel which has also reportedly degraded the water quality. The lake volume has decreased from 20.95 million $\mathrm{m}^{3}$ in 2001 to 15.35 million $\mathrm{m}^{3}$ in 2019 . Besides, unprecedented urban growth and permanent agriculture are steadily encroaching on the lake area reducing the extent of the marsh vegetation rapidly. Furthermore, when all the water parameters are treated independently for the calculation of contribution to the decrease or increase of storage capacity, validation with the help of the correlation matrix revealed that that water volume is affected by both water surface area $(r=0.951)$ and water level $(r=0.809)$. Therefore, what matters more at this hour are the well-planned conservative measures to be undertaken to stem these distressing problems suffered by such urban lakes. Deepor Beel is the only Ramsar site located in Assam and it's natural feature benefits the surrounding regions. But disorderly development along the lake may reduce its capability of water storage and flood regulation.

Although, the Government had proposed a sewage treatment plant as well as the shifting of the garbage dump. These plans need to be executed at the earliest as at this point, it is also necessary to create a sustainable balance in the restoration of the Beel as well as sustaining the livelihood of the fishermen. In this regard, aquaculture and sustainable methods of fishing could be employed; or alternate livelihood could be taught to the villages that depend on fishing. Even though Deepor Beel has been stripped of its glory in the past decades, proper implementation and coordination of the various administrative, social and legal frameworks together should be capable of restoring the Beel and prevent further degradation. Although, the task is an uphill one, but with an appropriate policy and effective management, Assam's lone Ramsar site can still be restored.

\section{References}

Adrian, R., Hessen, D., Blenckner, T., Hillebrand, H., Hilt, S., Jeppesen, E., Livingstone, D.N. and Trolle, D. (2016), "Environmental impacts - lake Ecosystems", in Quante, M. and Colijn, F. (Eds), North Sea Region Climate Change Asse, pp. 315-340.

Adugna, D., Lemma, B., Sahilu Gebrie, G., Larsen, L., Yeshitela, K. and Bergen Jensen, M. (2018), "Stormwater impact on water quality of rivers subjected to point sources and urbanization - the case of Addis Ababa, Ethiopia”, Water and Environment Journal, Vol. 33 No. 1, pp. 98-110.

Arabsahebi, R., Voosoghi, B. and Tourian, M. (2019), "A denoising-classification-retracking method to improve spaceborne estimates of the water level-surface-volume relation over the Urmia Lake in Iran”, International Journal of Remote Sensing, Vol. 41 No. 2, pp. 506-533.

Ay, M. and Kisi, O. (2015), "Investigation of trend analysis of monthly total precipitation by an innovative method", Theoretical and Applied Climatology, Vol. 120, pp. 617-629.

Bastawesy, M., Khalaf, F. and Arafat, S. (2008), "The use of remote sensing and GIS for the estimation of water loss from Tushka lakes, Southwestern desert, Egypt", Journal of African Earth Sciences, Vol. 52 No. 3, pp. 73-80.

Bhattacharyya, K.G. and Kapil, N. (2010), "Impact of urbanization on the quality of water in a natural reservoir: a case study with the Deepor Beel in Guwahati city, India”, Water and Environment Journal, Vol. 24 No. 2, pp. 83-96.

Cai, Y., Ke, C. and Shen, X. (2020), "Variations in water level, area and volume of Hongze Lake, China from 2003 to 2018”, Journal of Great Lakes Research, Vol. 46 No. 6, pp. 1511-1520.

Crétaux, J.F., Abarca-del-Río, R., Bergé-Nguyen, M., Arsen, A., Dro-lon, V., Clos, G. and Maisongrande, P. (2016), "Lake volume monitoring from space", Surveys in Geophysics, Vol. 37, pp. 269-305.

Dash, S., Borah, S. and Kalamdhad, A. (2019), "A modified indexing approach for assessment of heavy metal contamination in Deepor Beel, India”, Ecological Indicators, Vol. 106, 105444. 
Deb, S., Saikia, J. and Kalamdhad, A. (2019), "Ecology of Deepor Beel wetland, a Ramsar site of Guwahati, Assam with special reference to algal community", European Journal of Biomedical and Pharmaceutical Sciences, Vol. 6 No. 5, pp. 232-243.

Downing, J., Cole, J., Middelburg, J., Striegl, R., Duarte, C., Kortelainen, P., Prairie, Y.T. and Laube, K.A. (2008), "Sediment organic carbon burial in agriculturally eutrophic impoundments over the last century", Global Biogeochemical Cycles, Vol. 22 No. 1, pp. 1-10.

Duhan, D. and Pandey, A. (2013), "Statistical analysis of long term spatial and temporal trends of precipitation during 1901-2002 at Madhya Pradesh, India", Atmospheric Research, Vol. 122, pp. 136-149.

Elmahdy, S., Mohamed, M. and Ali, T. (2020), "Land use/land cover changes impact on groundwater level and quality in the northern part of the United Arab Emirates", Remote Sensing, Vol. 12 No. 11, p. 1715, doi: 10.3390/rs12111715.

Ganaie, T., Sahana, M. and Hashia, H. (2017), "Assessing and monitoring the human influence on water quality in response to land transformation within Wular environs of Kashmir Valley", Geojournal, Vol. 83 No. 5, pp. 1091-1113.

Geng, M., Wang, K., Yang, N., Li, F., Zou, Y., Chen, X., Deng, Z. and Xie, Y. (2021), "Spatiotemporal water quality variations and their relationship with hydrological conditions in Dongting Lake after the operation of the Three Gorges Dam, China”, Journal of Cleaner Production, Vol. 283, p. 124644.

Ghosh, S. (2019), "A city growth and land-use/land-cover change: a case study of Bhopal, India”, Modeling Earth Systems and Environment, Vol. 5, pp. 1569-1578.

Goswami, C. (2012), "Ichthayofaunal diversity \& anthropogenic stress on Deepor Beel: the only Ramsar site in Assam”, IOSR Journal of Environmental Science, Toxicology and Food Technology, Vol. 2 No. 1, pp. 54-59, doi: 10.9790/2402-0215459.

Goswami, M.M., Deka, T.K., Singh, P.K., Sarma, P.K. and Kakati, M. (1999), "Studies of some wetlands of Assam with reference to the eutrophication stresses", Journal of the Inland Fisheries Society of India, Vol. 31 No. 2, pp. 39-43.

Holgerson, M. and Raymond, P. (2016), "Large contribution to inland water $\mathrm{CO}_{2}$ and $\mathrm{CH} 4$ emissions from very small ponds", Nature Geoscience, Vol. 9 No. 3, pp. 222-226.

Islam, S. and Gnauck, A. (2008), "Mangrove wetland ecosystems in Ganges-Brahmaputra delta in Bangladesh", Frontiers of Earth Science, Vol. 2 No. 4, pp. 439-448.

Joshi, A. and Solanki, V. (2019), "Degradation and conservation of Indian Ramsar wetlands: a study of Loktak Lake and Deepor Beel”, Our Heritage, Vol. 67 No. 5, pp. 71-90.

Kendall, M.G. (1957), "Rank correlation methods”, Biometrika, Vol. 44 Nos 1/2, p. 298, doi: 10.2307/ 2333282.

Kumar, R., Bahuguna, I.M., Ali, S.N. and Singh, R. (2020), "Lake inventory and evolution of glacial lakes in the Nubra-Shyok basin of Karakoram range", Earth Systems and Environment, Vol. 4, pp. 57-70.

Lane, C. and D'Amico, E. (2010), “Calculating the ecosystem service of water storage in isolated wetlands using LiDAR in north central Florida, USA", Wetlands, Vol. 30 No. 5, pp. 967-977.

Liu, W., Ma, L. and Abuduwaili, J. (2020), "Anthropogenic influences on environmental changes of lake Bosten, the largest inland freshwater lake in China", Sustainability, Vol. 12 No. 2, p. 711.

Lu, S., Ouyang, N., Wu, B., Wei, Y. and Tesemma, Z. (2013), "Lake water volume calculation with time series remote-sensing images", International Journal of Remote Sensing, Vol. 34 No. 22, pp. $7962-7973$.

Mallick, J. (2017), "Hydrogeochemical characteristics and assessment of water quality in the Al-Saad Lake, Abha Saudi Arabia”, Applied Water Science, Vol. 7, pp. 2869-2882.

Mann, H.B. (1945), "Nonparametric tests against trend”, Econometrica, Vol. 13 No. 3, p. 245, doi: 10. 2307/1907187. 
FEBE 1,1
McFeeters, S. (1996), "The use of the Normalized Difference Water Index (NDWI) in the delineation of open water features", International Journal of Remote Sensing, Vol. 17 No. 7, pp. 1425-1432.

Medina, C., Gomez-Enri, J., Alonso, J. and Villares, P. (2010), "Water volume variations in lake izabal (Guatemala) from in situ measurements and ENVISAT radar altimeter (RA-2) and advanced synthetic aperture radar (ASAR) data products", Journal of Hydrology, Vol. 382 Nos 1-4, pp. 34-48.

Messager, M., Lehner, B., Grill, G., Nedeva, I. and Schmitt, O. (2016), "Estimating the volume and age of water stored in global lakes using a geo-statistical approach", Nature Communications, Vol. 7, 13603.

Mi, H., Zai, J. and Jiang, X. (2007), "Contrast and analysis of reservoir storage -calculation methods", Surveying and Mapping of Geology and Mineral Resources, Vol. 23, pp. 1-4 (in Chinese).

Mishra, R.S. and Griffin, A.L. (2010), "Encroachment: a threat to resource sustainability in Chilika Lake, India”, Applied Geography, Vol. 30 No. 3, pp. 0-459, doi: 10.1016/j.apgeog.2009.12.001.

Modi, A., Jokhio, C., Khongthaw, B., Nongrem, T., Pakam, R. and Kanikar, B. (2019), "Analysis of sediment contamination of Deepor Beel, Guwahati, Assam, India", International Research Journal of Engineering and Technology (IRJET), Vol. 6 No. 7, pp. 1397-1400.

Mozumder, C. and Tripathi, N.K. (2014), "Geospatial scenario based modelling of urban and agricultural intrusions in Ramsar wetland Deepor Beel in Northeast India using a multi-layer perceptron neural network", International Journal of Applied Earth Observation and Geoinformation, Vol. 32, pp. 92-104.

Mozumder, C., Tripathi, N. and Tipdecho, T. (2014), "Ecosystem evaluation (1989-2012) of Ramsar wetland Deepor Beel using satellite-derived indices", Environmental Monitoring and Assessment, Vol. 186 No. 11, pp. 7909-7927.

Mundoli, S., Manjunath, B. and Nagendra, H. (2014), "Effects of urbanisation on the use of lakes as commons in the Peri-urban interface of Bengaluru, India”, International Journal of Urban Sustainable Development, Vol. 7 No. 1, pp. 89-108.

NRSA (1995), "Natural resource census- land use land cover database. Technical report - Ver.1", available at: https://bhuvan-app1.nrsc.gov.in/2dresources/thematic/2LULC/lulc1112.pdf (accessed December 2020).

Panwar, S. (2017), "Evaluating land use/land cover change dynamics in Bhimtal lake catchment area, using remote sensing \& GIS techniques", Journal of Remote Sensing and GIS, Vol. 6 No. 2, 1000199.

Pawe, C. and Saikia, A. (2017), "Unplanned urban growth: land use/land cover change in the Guwahati Metropolitan Area, India”, Geografisk Tidsskrift-Danish Journal of Geography, Vol. 118 No. 1, pp. 88-100.

Rahman, A., Kumar, S., Fazal, S. and Siddiqui, M.A. (2012), "Assessment of land use/land cover change in the north-west district of Delhi using remote sensing and GIS techniques", Journal of the Indian Society of Remote Sensing, Vol. 40 No. 4, pp. 689-697.

Rashid, I. and Aneaus, S. (2020), "Landscape transformation of an urban wetland in Kashmir Himalaya, India using high-resolution remote sensing data, geospatial modeling, and ground observations over the last 5 decades (1965-2018)", Environmental Monitoring and Assessment, Vol. 192 No. 10, doi: 10.1007/s10661-020-08597-4.

Saha, S., Sarkar, D., Mondal, P. and Goswami, S. (2020), "GIS and multi-criteria decision-making assessment of sites suitability for agriculture in an anabranching site of Sooin River, India", Modeling Earth Systems and Environment, Vol. 7 pp. 571-588, doi: 10.1007/s40808-020-00936-1.

Sen, P.K. (1968), "Estimates of the regression coefficient based on Kendalls Tau", Journal of the American Statistical Association, Vol. 63 No. 324, pp. 1379-1389.

Seto, K.C., Güneralp, B. and Hutyra, L.R. (2012), "Global forecasts of urban expansion to 2030 and direct impacts on biodiversity and carbon pools", PNAS, Vol. 109 No. 40, pp. 16083-16088.

Shahjahan, A.T.M. and Ahmed, K.S. (2016), "Study of urban water bodies in view of potential for micro-climatic cooling and natural purification of waste water", in Maheshwari, B., 
Thoradeniya, B. and Singh, V.P. (Eds), Balanced Urban Development: Options and Strategies for Liveable Cities. Water Science and Technology Library, Springer, Cham, Vol. 72, pp. 199-209, doi: 10.1007/978-3-319-28112-4_13.

Silva, R.M., Santos, C.A., Moreira, M., Corte-Real, J., Silva, V.C. and Medeiros, I.C. (2015), "Rainfall and river flow trends using Mann-Kendall and Sen's slope estimator statistical tests in the Cobres River basin”, Natural Hazards, Vol. 77 No. 2, pp. 1205-1221, doi: 10.1007/s11069-0151644-7.

Sivanpillai, R. and Miller, S. (2010), "Improvements in mapping water bodies using ASTER data", Ecological Informatics, Vol. 5 No. 1, pp. 73-78.

Song, C., Huang, B. and Ke, L. (2013), "Modeling and analysis of lake water storage changes on the Tibetan plateau using multi-mission satellite data", Remote Sensing of Environment, Vol. 135, pp. 25-35, doi: 10.1016/j.rse.2013.03.013.

Sterner, R.W., Keeler, B., Polasky, S., Poudel, R., Rhude, K. and Rogers, M. (2020), "Ecosystem services of earth's largest freshwater lakes”, Ecosystem Services, Vol. 41, p. 101046, doi: 10.1016/j.ecoser. 2019.101046.

Tabari, H. (2019), "Statistical analysis and stochastic modelling of hydrological extremes", Water, Vol. 11 No. 9, p. 1861.

Talukdar, S. and Pal, S. (2019), "Wetland habitat vulnerability of lower Punarbhaba river basin of the uplifted Barind region of Indo-Bangladesh”, Geocarto International, Vol. 35 No. 8, pp. 857-886, doi: 10.1080/10106049.2018.1533594.

Talukdar, S., Mankotia, S., Shamimuzzaman, M., Shahfahad and Mahato, S. (2021), "Wetlandinundated area modeling and monitoring using supervised and machine learning classifiers", in Pandey and Sharma (Eds), Advances in Remote Sensing for Natural Resource Monitoring, John Wiley \& Sons, New Jersey, pp. 346-364, doi: 10.1002/9781119616016.ch17.

Taubenböck, H., Wurm, M., Netzband, M., Zwenzner, H., Roth, A., Rahman, A. and Dech, S. (2011), "Flood risks in urbanized areas - multi-sensoral approaches using remotely sensed data for risk assessment", Natural Hazards and Earth System Sciences, Vol. 11, pp. 431-444.

Tilahun, S. and Kifle, D. (2020), "Atmospheric dry fallout of macronutrients in a semi-arid region: an overlooked source of eutrophication for shallow lakes with large catchment to lake surface area ratio", Earth Systems and Environment. doi: 10.1007/s41748-020-00162-w.

Wada, Y., Reager, J.T., Chao, B.F., Wang, J., Lo, M.H., Song, C., Li, Y. and Gardner, A.S. (2016), "Recent changes in land water storage and its contribution to sea level variations", Surveys in Geophysics, Vol. 38 No. 1, pp. 131-152.

Wang, H. and Ma, M. (2016), "Impacts of climate change and anthropogenic activities on the ecological restoration of wetlands in the Arid regions of China”, Energies, Vol. 9 No. 3, p. 166, doi: 10.3390/ en9030166.

Winslow, L., Read, J., Hanson, P. and Stanley, E. (2015), "Does lake size matter? Combining morphology and process modelling to examine the contribution of lake classes to populationscale processes", Inland Waters, Vol. 5 No. 1, pp. 7-14.

Wu, J., Xue, C., Tian, R. and Wang, S. (2017), "Lake water quality assessment: a case study of Shahu Lake in the semiarid loess area of northwest China”, Environmental Earth Sciences, Vol. 76, p. 232.

Wufu, A., Wang, H., Chen, Y., Rusuli, Y., Ma, L., Yang, S., Zhang, F., Wang, D., Li, Q. and Li, Y. (2020), "Lake water volume fluctuations in response to climate change in Xinjiang, China from 2002 to 2018", Peerj, Vol. 8, e9683.

$\mathrm{Xu}, \mathrm{H}$. (2006), "Modification of normalised difference water index (NDWI) to enhance open water features in remotely sensed imagery", International Journal of Remote Sensing, Vol. 27 No. 14, pp. 3025-3033.

Yan, R., Gao, Y., Li, L. and Gao, J. (2019), "Estimation of water environmental capacity and pollution load reduction for urban lakeside of Lake Taihu, eastern China”, Ecological Engineering, Vol. 139, 105587, doi: 10.1016/j.ecoleng.2019.105587. 
FEBE 1,1

Yang, K., Luo, Y., Chen, K., Yang, Y., Shang, C., Yu, Z., Xu, J. and Zhao, Y. (2020), "Spatial-temporal variations in urbanization in Kunming and their impact on urban lake water quality", Land Degradation and Development, Vol. 31 No. 11, pp. 1392-1407.

Yao, X., Liu, S., Sun, M., Wei, J. and Guo, W. (2012), "Volume calculation and analysis of the changes in moraine-dammed lakes in the North Himalaya: a case study of Longbasaba lake", Journal of Glaciology, Vol. 58 No. 210, pp. 753-760.

Yin-Xi, G., Fei, Y., Zhong-Ke, F., Yun-Feng, L. and Wen-Xing, X. (2016), "Extraction of crown volume using triangulated irregular network algorithm based on LiDAR", Journal of Infrared and Millimetre Waves, Vol. 35 No. 2, pp. 178-189.

Zhang, G., Yao, T., Shum, C., Yi, S., Yang, K., Xie, H., Feng, W., Bolch, T., Wang, L., Behrangi, A., Zhang, H., Wang, W., Xiang, Y. and Yu, J. (2017), "Lake volume and groundwater storage variations in Tibetan Plateau's endorheic basin”, Geophysical Research Letters, Vol. 44 No. 11, pp. 5550-5560.

Zhang, G., Chen, W. and Xie, H. (2019), “Tibetan plateau's lake level and volume changes from NASA's ICESat/ICESat-2 and Landsat missions", Geophysical Research Letters, Vol. 46 No. 22, pp. 13107-13118.

\section{Further reading}

Hayashi, M. and van der Kamp, G. (2000), "Simple equations to represent the volume-area-depth relations of shallow wetlands in small topographic depressions", Journal of Hydrology, Vol. 237 Nos 1-2, pp. 74-85.

Homepage | Ramsar (2003), available at: https://www.ramsar.org/ (accessed 9 November 2019).

Minke, A., Westbrook, C. and van der Kamp, G. (2010), "Simplified volume-area-depth method for estimating water storage of prairie potholes", Wetlands, Vol. 30 No. 3, pp. 541-551.

Thakur, J., Singh, S. and Ekanthalu, V. (2016), "Integrating remote sensing, geographic information systems and global positioning system techniques with hydrological modelling", Applied Water Science, Vol. 7 No. 4, pp. 1595-1608.

Wilcox, C. and Huertos, M. (2005), "A simple, rapid method for mapping bathymetry of small wetland basins”, Journal of Hydrology, Vol. 301 Nos 1-4, pp. 29-36.

\section{Corresponding author}

Atiqur Rahman can be contacted at: arahman2@jmi.ac.in

For instructions on how to order reprints of this article, please visit our website:

www.emeraldgrouppublishing.com/licensing/reprints.htm

Or contact us for further details: permissions@emeraldinsight.com 